\title{
Evaluation and Protection of Library Collections with Heritage Value. Establishing Ante-Digitization and Post-Digitization Measures
}

\author{
Vasile Deac \\ Researcher, PhD \\ "Gh. Sincai" County Library of Bihor, Oradea \\ E-mail Vasile_deac@yahoo.com \\ Ionela Burz \\ Librarian, PhDc \\ University of Oradea Library \\ E-mail ionela_burz@yahoo.com \\ Alexandru Deac \\ Specialist in systems engineering and environmental biotech \\ Inteva Company Ltd., Oradea \\ E-mail deac.alex38@yahoo.com
}

In this article, the authors present, on the basis of the scientific arguments obtained through laboratory experiments, some pertinent aspects regarding: the evaluation and preservation of the digitized collections; presentation of conditions for the digitization of valuable library documents; presentation of ante- and post-digitization measures for library collections that are subject to digitization.

This scientific approach is designed to preserve digitized libraries, collections and documents, being an essential scientific activity that takes place in parallel with the conservation of information from digitized products.

Keywords: preservation; digitized collections; library documents; ante-digitization measures; post-digitization measures

\section{Argument}

Libraries that hold collections of valuable documents must consider digitization as an active way of preserving that avoids the communication of originals, but not as a long-term preservation method, a position shared by most modern library specialists. The preservation of these assets in locked deposits is the detrimental practice of the old book specialist as well as of the manager directly responsible for the integrity and security of the managed documents.

Given the remarkable value of these old and rare, sometimes unique documents, it is nevertheless the fears of the manager, the old book specialist and the library conservator to have reservations to lend the documents for consultation in the reading rooms of the institution under the direct supervision of the specialists. These hesitations are justified up to a certain point. Beyond assuming these fears about ensuring the security and integrity of the documents, one question arises: How are patrimonial documentary assets made known? Only through exhibitions or some thematic presentations? The results are known: this very valuable fund of a library is less well known and researched.

As a consequence, the preservation of the electronic documents has certain advantages for the institutions that have impressive collections, such as libraries and archives. By creating digital substitutes, these institutions preserve their original documents, thus prolonging their physical and informational integrity. Digitization of the heritage documents also means the setting up of the Digital Heritage Library, which includes collections created by the libraries through the

Revista Română de Biblioteconomie şi Ştiința Informării = Romanian Journal of Library and Information Science ISSN 2559-5490, ISSN-L 1841-1940 • Volume 15 Issue 22019 pp. 51-60 https://doi.org/10.26660/rrbsi.2019.15.2.51

This work is licensed under a Creative Commons Attribution-NonCommercial-NoDerivatives 4.0 International License 
Evaluation and Protection of Library Collections with Heritage Value.

Establishing Ante-Digitization and Post-Digitization Measures

digitization of old and rare collections on organic support to make them known and accessible to a wider and more informed audience. Therefore, the rationale for digitizing the heritage assets in libraries, archives and museums involves multiple objectives, including the preservation of the original.

In summary, digitization transforms analogue data (readable by humans) into digital form (represented by figures and machine readable) and covers all types of documents on different supports: paper, microforms (microfiche, microfilm), photos, video/audio tapes. In a library and archive environment, digitization involves: photographing of analogous items such as books, magazines, maps, correspondence, manuscripts, press collections, etc. which are the subject of rare, unique, extremely fragile collections and then their transfer into a digital environment.

In the literature, the preventive and curative preservation is defined as the set of preventive and curative interventions performed in the libraries, museums and archives, especially in the morphological structure of the documents, for investigation, stopping and eradication of the identified degradation factors. As a rule, curative interventions (treatments) are achieved by using non-invasive, non-polluting techniques and methods, embedded in integrated systems adapted to the degradation factors and levels under investigation. When choosing an intervention system adapted to the morphological particularities of the documents, the emphasis should be placed on the balance between the preventive and the curative intervention system, with a particular emphasis on the preventive methods (Deac 2009).

The digitization of valuable collections in libraries, museums and archives analyzes all types of documents in the cultural institutions and can be achieved from various information-carrier supports: paper; microforms (microfiche, microfilm); photos; video/audio tapes.

In a library environment, digitization involves photographing analogous items such as valuable books, maps, manuscripts, correspondence, etc. which are part of rare, unique, and extremely fragile collections, and then transforming these photos into a digital environment. In the literature and practice on digitizing the paper documents, two technical ways of intervention are known: a way in which the scanning of the document produces digital images (doesn't allow the search in the text) and a way that goes further by transforming the digital images into digital text. The digitization of library documents to obtain the digital image as the ultimate product is the easiest and least costly technical way, being within the reach of each library. Digital images are obtained by photographing each document page, generating thus a copy of the original document in electronic facsimiles (represents a binary language). To facilitate the access to the digital document as a picture, a complete bibliographic description is required. The digital image is processed using an optical character recognition program (software that recognizes the characters optically with a rate of $80-95 \%$ ). This technique allows the document content to be retrieved as text. Thus, it is possible to search in the text or "document browsing" (operation that allows fast accessing-movement within the information, for example from the contents to a chapter or other) and the easy and direct access of the users (more or less familiar with the domain) to the information.

Briefly, some fundamental aspects of the domains devoted to the protection of documents in libraries, museums and archives have been presented to highlight not only the application domains but also the possible links that can be established in preserving the material support and text of the library and archive documents.

\section{Motivations}

The evaluation and protection in time of the valuable digitized collections of documents from libraries (archives and museums) represents methodologically, but above all practically, a field of 
Evaluation and Protection of Library Collections with Heritage Value.

Establishing Ante-Digitization and Post-Digitization Measures

document protection with recent data requirements and structures, as a result of speeding up the digitization of valuable documents on organic support. The transfer of information from organic support to digital (electronic) support involves the development and use of cutting-edge techniques and methodologies, a modern infrastructure, as well as a flawless training of the specialists involved in this very demanding activity. The need to transfer valuable information on paper support, on the electronic-numeric support by digitizing the library documents is not questioned. The benefits of digitizing valuable library documents are known by all professionals involved in this professional process, be they classical conservators - paper conservators or conservators of digitized information (numerically and electronically).

The main issues that represent motivational imperatives for the development and implementation of the roadmap, for the categorical and unconditional protection needs through preventive and/or curative interventions to preserve valuable documents that are digitized, are listed below:

a. preparation of documents for digitization;

b. development and application of methodologies to investigate the state of conservation and evaluation of the interest scientific parameters of the documents proposed for digitization;

c. choosing pre-digitization and post-digitization intervention systems adapted to the morphological and chemical characteristics of the paper types used (origin and quality of paper, inks and pigments, etc.); investigation and evaluation of the state of preservation of post-digitized documents;

d. development and application of scanning objectives for the documents of a public library.

Some of the advantages of library document digitization are highlighted without insisting on their quality and impact in different intra- and inter-library situations:

- for the documents of national cultural heritage value of venerable age, digitization creates conditions for keeping, preserving and protection in individual conservation modules, thus prolonging the existence of valuable cultural info assets;

- digitization of documents of national and/or local interest ensures unlimited access to valuable information on various electronic-numerical supports, thus protecting the documents on the paper;

- by digitizing the documents often requested by the general public, that is an information consumer, conditions are created for the redistribution of the copies in cultural institutions with a surplus of documents of public interest to other libraries;

- through the digitization of valuable documents of community interest, the library holding the classical documents (on paper) offers for research the electronic documents under different numerical supports, protecting the classical ones, including through the elaboration of an efficient typo storage system according to the typo-dimensioning of documents in different formats;

- digitization is carried out for scientific purpose, in order to capitalize on the scientific content of the documents, by facilitating the access;

- the digitization of valuable documents is a patrimonial-oriented approach, by storing and preserving the information on several material supports;

- digitization of original documents that are in critical conservation state (fragile, breakable);

digitization of documents on organic media/supports to facilitate the remote access - digital information on the web allows users to quickly search for and retrieve collections anytime, anywhere;

- digitizing valuable documents from libraries, museums and archives encourages and stimulates the multidisciplinary research by increasing the access to valuable information;

- electronic conversion of the written cultural heritage and its promotion at European level.

Digitization offers unique advantages: information can be provided to the remote user; image quality can be fairly good; "full text" search facility; the flexibility of digital content - is reflected in the fact that the information is not as fixed as printed on paper, being easily reformulated; digitization offers the possibility of accessing unique or special collections (which, as a rule, could 


\section{Evaluation and Protection of Library Collections with Heritage Value.}

Establishing Ante-Digitization and Post-Digitization Measures

only be viewed by one person) to a large number of users, which is the most attractive practical application of the digitization project, since a large audience's access to digital copies of the original materials brings a great service to the library and equally to the users of this institution.

The specialists working in libraries must understand that digitization not only exploits the existing resources but can bring a new breath to a classic library. Exposing collections on the Internet and thereby increasing access to these documents is an effective way of reporting and promoting collections from a virtual, borderless library (Popovici 2004).

The inconveniences that occur in the digitization of collections of documents in libraries, museums and archives:

a. several inconveniences occur mainly due to the optical character recognition programs that:

- change the original layout of the page;

- generate certain character recognition errors, which involves checking (re-reading) and correcting the text, an often difficult and tedious activity;

- inconveniences of the digital text due to optical character recognition programs that: modify the original layout of the page; do not recognize the characters from non-Latin alphabets, as well as some diacritical signs and manuscript writings.

b. Most inconveniences with regard to the final quality of the digital library document depends on the following factors: the quality of the original document - the printing ink; paper support and contrast that can be degraded over time; scanning/shooting quality;

c. Despite the benefits of the library collection digitization, there are some good reasons to analyze this area more closely: not every document deserves to be digitized; it is a long way to accomplish the objective that all libraries will be fully accessible online, a project which, in the opinion of many specialists, is impossible to achieve; only if collections are carefully evaluated and the documents of local and national interest are digitized, the digital projects can be successful;

d. Digital projects are very expensive; the need for specialized personnel and state-of-the-art technical infrastructure often involves the highest costs in the project:

- it takes a lot of time to train the staff directly involved in running the projects and selecting the items to digitize;

- costs for ongoing digitization and project completion;

- costs for maintaining the digital media to ensure the readings in the future;

- most attempts to recover the cost of digital representation through user charges did not cover the spent financial effort;

e. Digitization is not yet a preservation mode that is based on a stable long-term storage environment; the only long-term acceptable support of storage is the quality paper or microfilm;

f. In many cases, the access to successful digital surrogates encourages the users to consult the original document, fact that generates additional services and costs for phones, letters, reproduction requests for original documents; as such, digitized documents must be of good quality to meet the quality standards imposed by users - consumers of information.

In conclusion, before starting a project of digitizing valuable documents from libraries, museums and archives, it is advisable to know the answer to a series of questions that should explain the whole process:

- what will be the gain by digitizing valuable library, museum or archive documents?;

- if the structure of the document digitization project is known, taking into account the particularities of the institution: the structure, value and the conservation status of the collections of documents: the presence of conservative specialists, as well as a conservation laboratory?;

- how will this project fit in the institution's activities (goals)?;

what costs does this project require, if they are affordable and what are the benefits that can be 
gained?

- how will this project fit in the activities of the institution?;

- what will be the impact of the project on the targeted public?

- what are the methods for checking the effectiveness of the project, whether it has been successful or not?;

- whether the legislative, regulatory and normative framework has been established, which serves as the basis for creating management and compliance tools with the legal aspects of digitization, namely: visibility, interoperability, integrity, authenticity, updating and sustainability of information? (ISO 2001a and 2001b)

- what are the methods for verifying the effectiveness of the project, whether it has been successful or not?

\section{Contributions on the stage development of a document digitization project in a public library}

The digitization of collections involves a series of prerequisites and activities designed to describe the scope, value and importance to justify the effort (Alkhoven 1999). Digitization involves a number of prerequisites: the representativeness of collections; the importance of the user group; conservation reasons.

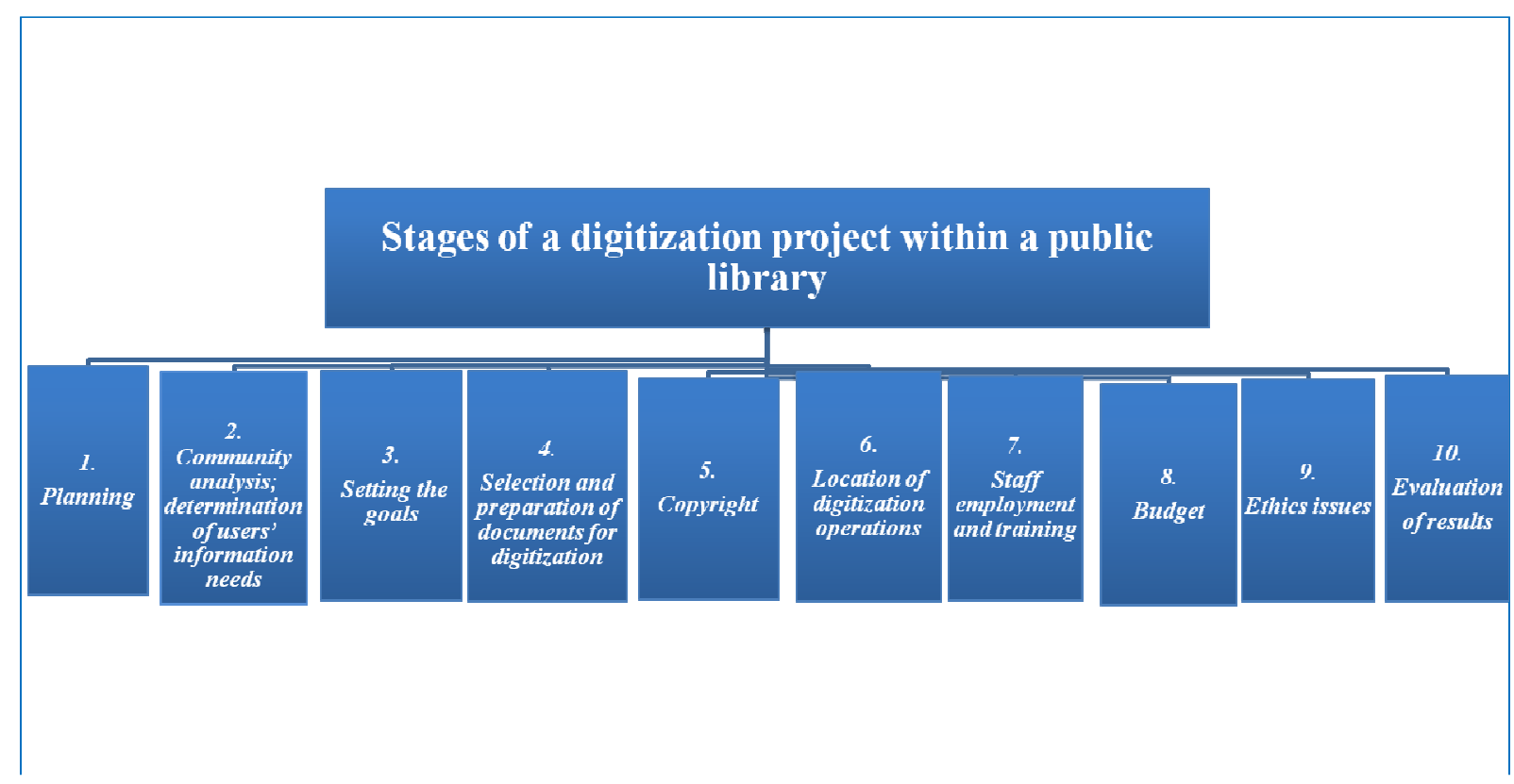

Figure 1

In Table 1 are detailed the main steps of the digitization project at an important public library.

Table 1. Stages of a digitization project within a public library

\begin{tabular}{|l|l|l|}
\hline $\begin{array}{l}\text { Crt. } \\
\text { no. }\end{array}$ & $\begin{array}{c}\text { Stages of project } \\
\text { development }\end{array}$ & \multicolumn{1}{c|}{ Presentation of the digitization project stages } \\
\hline 1. & Planning & $\begin{array}{l}\text { Before starting a digitization project, it is advisable to know the } \\
\text { answer to a few questions that are crucial to the success of the project: } \\
\text { - what will be gain through digitization? } \\
\text { - how will this project fit to the purpose of the institution? } \\
\text { - what are the benefits? } \\
\text { - what are the ways of determining - quantifying the results of the } \\
\text { project - whether it was successful or not? }\end{array}$ \\
\hline
\end{tabular}


Evaluation and Protection of Library Collections with Heritage Value.

Establishing Ante-Digitization and Post-Digitization Measures

\begin{tabular}{|c|c|c|}
\hline 2. & $\begin{array}{l}\text { Community analysis; } \\
\text { determination of users } \\
\text { information needs }\end{array}$ & $\begin{array}{l}\text { Digitizing the documents in a library involves careful analysis of users } \\
\text { and their information needs. } \\
\text { Libraries' collections must be structured and thus digitized to meet the } \\
\text { needs of users' information. Such an analysis should provide the } \\
\text { following data: } \\
\text { - who are the users of information? } \\
\text { - what are the information needs? } \\
\text { - determination of the information behaviour; } \\
\text { - meeting the users' information needs by digitizing the } \\
\text { collections; } \\
\text { - how can information be used from different areas of activity? } \\
\text { - how can I transfer the information? } \\
\text { - what are the reasons for success or failure to inform? } \\
\text { - how will they use this digitized collection? } \\
\text { - how will more users access the digitized documents? } \\
\text { - what will be the benefits of the institution and users from the } \\
\text { use of digitized materials? }\end{array}$ \\
\hline 3. & Setting the goals & $\begin{array}{l}\text { The objectives of a digitization project can be of four types: } \\
\text { I. Preservation of documents. } \\
\text { - Preservation scan refers to documents whose support is outdated } \\
\text { and shows deterioration signs. The scanned copy is the copy that can } \\
\text { be consulted by users. } \\
\text { II. Distribution of documents } \\
\text { Distribution scan refers to documents that will be used as part of a } \\
\text { broadcast project such as an exhibition or to make the documents } \\
\text { accessible to users on the site or remotely. The original documents } \\
\text { will be retained, but the consultation will be done according to the } \\
\text { scanned copy. In order to facilitate the access to the digitized } \\
\text { documents on the Internet, the following aspects should also be } \\
\text { considered: } \\
\text { - who are the target users and what documents will they request?; } \\
\text { - how will they use this digitized collection?; } \\
\text { - how will more users access the digitized documents?; } \\
\text { - what will be the benefits of the institution and users from the use of } \\
\text { the digitized materials? } \\
\text { III. Saving Documents } \\
\text { - Scanning of the backup documents mainly concerns the documents } \\
\text { of vital importance to institutions (essential documents) and requires } \\
\text { the keeping of a second copy as a precautionary measure. Usually, } \\
\text { this backup copy will be made on a different support and preferably } \\
\text { stored in a place other than the originals. The original documents will } \\
\text { be kept, but the consultation will be done according to the scanned } \\
\text { copy. } \\
\text { IV. Substitution of documents } \\
\text { The purpose of substitution scanning is to: } \\
\text { - reduce the cost of maintaining the premises and collections, as well } \\
\text { as of the material resources needed to store the documents; } \\
\text { - facilitate the access to and consultation of online documents. } \\
\text { Original documents will be removed once they have been digitized } \\
\text { and a quality control validated their integrity. These projects must be } \\
\text { strictly regulated by laws, regulations and standards that ensure the } \\
\text { probative value of documents and their sustainability. }\end{array}$ \\
\hline
\end{tabular}




\begin{tabular}{|c|c|c|}
\hline 4. & $\begin{array}{l}\text { Selection and } \\
\text { preparation of } \\
\text { documents for } \\
\text { digitization }\end{array}$ & $\begin{array}{l}\text { The selection of documents from public libraries for their preservation } \\
\text { through digitization is determined by various objective factors, } \\
\text { including: } \\
\text { - the uniqueness of the document; } \\
\text { - its cultural, historical and scientific value; } \\
\text { - conservation state. } \\
\text { The selection of documents intended to be digitized is an essential } \\
\text { professional approach and is carried out by a team consisting of: } \\
\text { - an expert in preserving library collections, } \\
\text { - old book expert librarians. } \\
\text { - the IT digitization specialist, directly responsible for the quality of } \\
\text { digital surrogates. } \\
\text { The documents that are subject to digitization are carefully analyzed } \\
\text { and investigated by the conservative specialist who will prepare a pre- } \\
\text { digitization preservation file of the document, consisting of: pre- } \\
\text { digitization preservation sheet of the document; analysis bulletins on } \\
\text { the pH of the information carrier paper support (evolution graph and } \\
\text { statistical processing calculus); establishing the bio-pathological } \\
\text { diagnosis by microscopy determinations - elaboration of analysis } \\
\text { bulletins and other chemical and mechanical analyzes. }\end{array}$ \\
\hline 5. & Copyright & $\begin{array}{l}\text { The selection of library documents to be digitized is a topical } \\
\text { professional approach, which must firstly take into account the clear } \\
\text { understanding of copyright and related rights. In this respect, it must } \\
\text { be determined whether the concerned institution has the legal right to } \\
\text { digitize items and distribute them online, in compliance with the legal } \\
\text { framework. } \\
\text { The selection process starts by checking the restrictions imposed by } \\
\text { the ownership and the copyright of the documents and digitized } \\
\text { materials and continues with the compliance with the value criteria of } \\
\text { the documents (in Romania, Law } 8 / 1996 \text { on copyright and related } \\
\text { rights). } \\
\text { The Internet has put new pressure on the legislation to protect the } \\
\text { digital material. There are ways in which institutions can protect their } \\
\text { digital collections - access can be controlled by requesting passwords. }\end{array}$ \\
\hline 6. & $\begin{array}{l}\text { Location of digitization } \\
\text { operations }\end{array}$ & $\begin{array}{l}\text { General rules to be followed: specific operations on the digitization of } \\
\text { valuable documents will be designed to minimize the duration of } \\
\text { transport, handling and digitization, by respecting all specific } \\
\text { conservation and security measures for valuable documents. } \\
\text { Advantages of digitization at library headquarters: } \\
\text { - full control over digitization documents and operations; } \\
\text { - protecting documents against transport hazards; } \\
\text { - rapid evaluation of the quality of digitized documents and } \\
\text { corrections required; } \\
\text { - possibly cheaper, but cost is difficult to predict; } \\
\text { - specialization of its own personnel, without contractual obligations } \\
\text { towards a third party, in case of technical difficulties. } \\
\text { Disadvantages of digitization at library headquarters: } \\
\text { - costs may increase if technical-material execution difficulties arise } \\
\text { in the digitization project; } \\
\text { - providing air-conditioned and sanitized spaces for scanning } \\
\text { operations; } \\
\text { - careful management and supervision within the institution; } \\
\text {-security of the technical logistics of the contractor. }\end{array}$ \\
\hline
\end{tabular}




\begin{tabular}{|c|c|c|}
\hline 6. & $\begin{array}{l}\text { Location of } \\
\text { digitization } \\
\text { operations }\end{array}$ & $\begin{array}{l}\text { Benefits of using intermediaries - specialised companies: } \\
\text { - no hard drives or software (except those required to display images) } \\
\text { must be purchased; } \\
\text { - the beneficiary of the project does not provide secure locations for } \\
\text { maintaining the technical logistics used for digitization; } \\
\text { - the experience and expertise of the service provider can be used; } \\
\text { - known costs from the beginning; } \\
\text { - the provider has all the interest to use the most modern hard drives and } \\
\text { software. } \\
\text { Disadvantages of using intermediaries that are digitization service } \\
\text { providers: } \\
\text { - taking into account the fact that the digitization project will be put into } \\
\text { practice by a company outside the library, the careful management and } \\
\text { supervision from within is compulsory; } \\
\text { - sometimes the norming of the workload evidenced by digitized pages is } \\
\text { detrimental to the quality of the digitized images; } \\
\text { - automatic browsing of pages (about } 2000 \text { pages / hour) represents a risk } \\
\text { assumed by the performer, especially when working with fragile } \\
\text { documents that easily breaks down on aggressive manipulations; } \\
\text { - as such, it is necessary to check all project activities with the help of the } \\
\text { quality control grids corresponding to the digitization of documents. }\end{array}$ \\
\hline 7. & $\begin{array}{l}\text { Staff employment and } \\
\text { training }\end{array}$ & $\begin{array}{l}\text { Digital projects are a new professional approach requiring professional } \\
\text { technical knowledge and new skills: } \\
\text { - initiation and training of the existing staff in the new technology is a } \\
\text { necessity dictated by the new trends in the development of modern } \\
\text { libraries; } \\
\text { - even if the digitization project will be designed and developed by an } \\
\text { external company but also when a specialist is employed to work on the } \\
\text { project, the managerial policies of training the existing staff in learning the } \\
\text { basic notions and techniques in digitization are essential for all projects } \\
\text { that can be developed over time; } \\
\text { - the practice of working only with specialists outside of the library is } \\
\text { damaging and inevitably leads to compromising the library's commitment } \\
\text { to create a modern digital library; } \\
\text { - the wisest management policy, with beneficial and sustainable effects, } \\
\text { consists in training the library staff's IT specialists, as well as the } \\
\text { conservative experts and librarians specialist in protection and old books, } \\
\text { to prepare and run through the digitization of valuable collections of } \\
\text { documents. }\end{array}$ \\
\hline 8. & Budget & $\begin{array}{l}\text { The budget is the necessary financial condition for running the activity } \\
\text { programs in any institution. Year-to-year libraries have insufficient funds } \\
\text { to run forward-looking projects. } \\
\text { Library management needs to set forward investment priorities that bring } \\
\text { added value to the professional work of the library, as well as a modern } \\
\text { perspective for development. } \\
\text { In digital projects, from the allocated budget amount, important costs are } \\
\text { distributed to the training and improvement of the staff employed, on } \\
\text { which the quality of library services depends to a large extent. } \\
\text { A balanced budget for running a digitization project must include the } \\
\text { following categories of expenditure: } \\
\text { - wages (approximately } 50 \% \text { of the budget allocated for digitization); } \\
\text { - expenses for the professional training of the staff; } \\
\text { - funds for technical-logistics equipment; } \\
\text { - maintenance, license and communication costs; } \\
\text { - other unpredicted expenditure in the budget (about } 10 \% \text { of the budget } \\
\text { allocated to the project). }\end{array}$ \\
\hline
\end{tabular}




\begin{tabular}{|l|l|l|}
\hline 9. & Ethical issues & $\begin{array}{l}\text { Libraries must be responsible not only for the preservation of the } \\
\text { original goods but also for the digital goods deriving from the } \\
\text { original. } \\
\text { There is a problem for the security of the information that the library } \\
\text { currently holds. More specifically, how much and what information is } \\
\text { made available to the user online. Valuable information is required to } \\
\text { be safe. }\end{array}$ \\
\hline 10. & Evaluation of results & $\begin{array}{l}\text { The quality assessment of the digital product is done by examining } \\
\text { images under the form of digital products. } \\
\text { Evaluation of the digital product is sometimes a neglected step in the } \\
\text { digitization projects, but quality control is the most important part of } \\
\text { the digitization projects that can analyze and promote digital products } \\
\text { to the highest standards. } \\
\text { Many digital projects are evaluated by the number of digitized items - } \\
\text { a criterion that is not relevant to the success achievement, because the } \\
\text { digitization of thousands of images means nothing if they are of poor } \\
\text { quality, hard to locate in the database or there is a lack of interest from } \\
\text { the target audience. } \\
\text { In conclusion, the users of digital information are those who ensure } \\
\text { the qualitative assessment of digital projects by how long, how they } \\
\text { use and the way they use digital products. }\end{array}$ \\
\hline
\end{tabular}

\section{Conclusions and recommendations}

The digitization of valuable documents from libraries, museums and archives highlights the active collaboration of two professional structures with totally different roadmaps, but complementing each other to achieve the digitized support: the team of conservationists, restorers and operators in handling and browsing the documents for scanning and the team of digitizers who, with the help of a book scanner, translates the information from physical format (manuscript, book, press collections, etc.) into an electronic format PDF, TIF, JPG) for easier access to information from multiple locations.

Although the two teams have different training and professional preoccupations they must collaborate, even indirectly, to achieve the final product.

In the digitization process of selected documents, the protection team coordinated by the conservatory specialist for the protection of heritage documents organizes all the activities that ensure the protection of patrimonial assets on paper support in the pre-digitizing, scanning and post-scanning phases, as follows:

- preparation of documents for scanning (assessment of conservation status and carrying out treatments for the neutralization ofthe multifactorial degradation factors);

- handling of documents on the scanner (during the scanning process, the handling and browsing of documents will be done either directly by the conservator or by coordination in execution);

- proper operation of the scanning equipment (the conservator allows the scanning of documents only with high-performance professional equipment). 


\section{References}

Alkhoven, P. (1999) La numerisation des collections: les objectifs strategiques de la Bibliotheque Royale des Pays-Bas) [Digitizing collections: the strategic objectives of the Royal Library of the Netherlands], Bulletin des Bibliotheques de France, 44(6) pp. 80-87.

Banciu, D. (2001) Informatizarea bibliotecilor - concepte şi practici [Library automation: concepts and practices], București: Editura Universităţii din București.

Beagrie, N. (s.a.) Going Digital: issues in digitisation for public libraries [online], available: http://www.ukoln.ac.uk/public/earl/issuepapers/digitisation.htm.

Bureau de Coopération Interuniversitaire (2014) Guide de gestion d'un projet de numérisation [online], available: http://bit.ly/rrbsi22019f.

Deac, V. (2009) Conservarea colecţiilor infodocumentare din biblioteci, muzee şi arhive. Simptomatologia complexului de degradare [Conservation of infodocumentary collections in libraries, museums and archives. Symptomatology of the degradation complex], București: Centrul de Pregătire Profesională în Cultură.

International Organization for Standardization (ISO) (2001a) ISO 15489-1: 2001 (fr) : Information et documentation - „Records management”- Partie 1: Principes directeurs.

International Organization for Standardization (ISO) (2001b) ISO 15489-2: 2001 (fr) : Information et documentation - „Records management” - Partie 2: Guide pratique.

Legea nr. 8/1996, Actualizata 2014, privind dreptul de autor si drepturile conexe [Law no. 8/1996, updated 2014, on copyright and related rights] (2014) [online], available: http://bit.ly/rrbsi22019g.

Perrin, J.M., Winkler, H.M. and Yang, Le (2015). Digital Preservation Challenges with an ETD Collection - A Case Study at Texas Tech University, The Journal of Academic Librarianship, 41 (1) pp. 98-104, available: https://doi.org/10.1016/j.acalib.2014.11.002. 